\title{
INTEGRATION OF A GIS AND HEC-HMS MODELING TO IMPROVE URBAN RESILIENCE TO FLOOD RISK IN ALGIERS. ALGERIA
}

\author{
Khouas MAKHLOUF ADEL* \\ Urban and Environmental Analysis Laboratory, Badji Mokhtar University - Annaba \\ B.P.12, Annaba, 23000, Algeria, e-mail: makhlouf-adel.khouas@univ-annaba.org \\ Telaidjia DJAMEL \\ Urban and Environmental Analysis Laboratory, Badji Mokhtar University - Annaba \\ B.P.12, Annaba, 23000, Algeria, e-mail: telaidjia@univ-annaba.dz \\ Habibi YAHYAOUI \\ Laboratory LRNAT Institute of earth sciences and the universe, University of Batna 2 \\ Fésdis, Batna 05078, Algeria, e-mail: y.habibi@univ-batna2.dz
}

\begin{abstract}
Citation: Makhlouf Adel K., Djamel T., \& Yahyaoui H. (2021). INTEGRATION OF A GIS AND HEC-HMS MODELING TO IMPROVE URBAN RESILIENCE TO FLOOD RISK IN ALGIERS. ALGERIA. Analele Universităţii din Oradea, Seria Geografie, 31(2), 100-109. https://doi.org/10.30892/auog.312102-860
\end{abstract}

\begin{abstract}
The study of the phenomenon of flooding in an urban environment requires the integration of the city in its physical context, in this case the entire impluvium. Thus, the consideration of all the hydrological, morphometric and physical characteristics (topography, lithology, land cover...). In order to put in place appropriate measures to improve urban resilience and protect the population and their property in the capital of Algeria (City of Algiers), a hydrological modeling must be carried out upstream to evaluate the hydrological response of the watershed. This modeling was done using the auxiliary tool HEC-GEO HMS, an extension that works in a GIS environment (ArcGIS).
\end{abstract}

Key words: Algiers, Flooding, urban resilience, GIS, modelling, HEC-HMS.

$$
* \quad * \quad * \quad * \quad * \quad *
$$

\section{INTRODUCTION}

Flood risk is one of the most devastating natural hazards that cause loss of lives, damage to properties, resources and environmental degradation in urban areas (Sami, Adbelwahhab, Yahyaoui, \& Abdelhhani, 2021). Algeria is one of the countries facing the adverse effects of natural disasters, especially those related to river dynamics, such as floods. The wilaya of Algiers has experienced several floods and the return of experience from the Bab El Oued disaster on November 10, 2001 with more than 500 deaths, which constitutes a major concern for the authorities, a permanent fear for the inhabitants and a threat to public health and the environment.

\footnotetext{
* Corresponding Author
} 
Improving urban resilience in terms of managing different urban flood disaster scenarios requires the study of the watershed's response to rainfall. This response is a function of perennial characteristics over time, or assumed such at the scale of the phenomena studied (pedology, geology, surface area, slope, anthropogenic developments) and of characteristics that vary over time (rainfall history, soil moisture content, state of the plant cover, cultural practices, etc.) (Fouchier, 2010). That said, hydrological modeling is a complex phase that requires the interaction of a set of factors based on a wide variety of models. One of the most successful of these models is the spatial conceptual models that will be adopted.

It is in this perspective that our approach, which allows us to model the watershed in order to set up a flood forecasting tool, fits in. However, knowledge of the hydro-meteorological hazard is a crucial step in the management of a possible crisis.

\section{PRESENTATION OF THE STUDY AREA}

Algiers is the economic and political capital of Algeria. It is home to the largest port in Algeria, and although it is the smallest province in terms of surface area, it is the most densely populated. It is a multifaceted city with the most important financial, political and administrative functions in the country. Urban facilities of national and international influence are concentrated in Algiers: airports, university hospitals, universities and graduate schools. Algiers has been inhabited since antiquity and has a rich history.

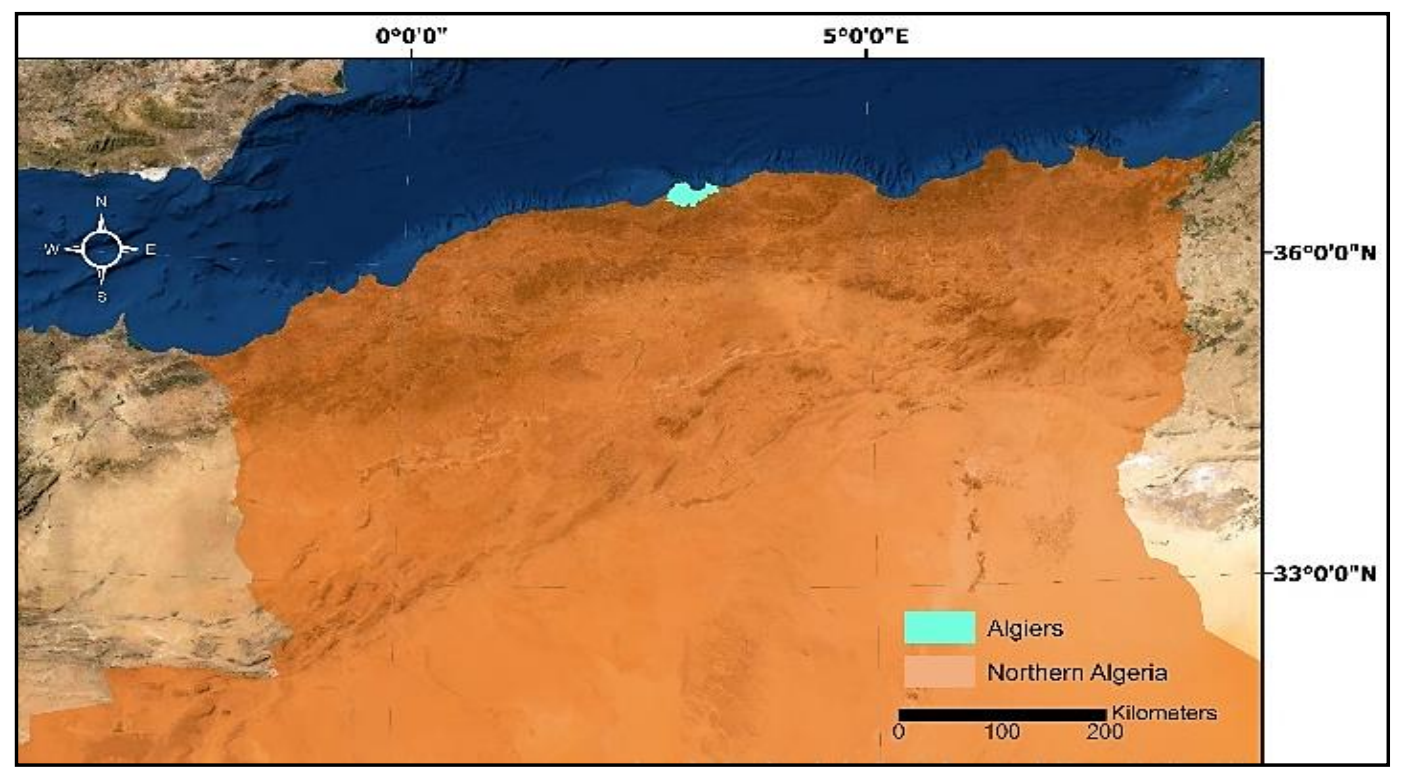

Figure 1. Algiers site

(Source: Khouas Makhlouf Adel)

\section{MATERIAL AND METHODS}

\section{Hydrological modeling}

Hydrological modeling aims to reproduce the hydrological behavior of a watershed (Beckers \& Degré, 2011). It provides information that can be used for the dimensioning of hydraulic works, flood protection or for the hydrological management of a watershed (Gnouma, 2006). Hydrological modeling consists in describing the different stages of the rain-flow transformation which is part of the process linked to the genesis of floods, it provides useful information for the preparation of a possible crisis. Hydrologic models describing the transformation of rainfall over a watershed to runoff at its outlet depend on the physical description of the watershed (Castro \& Maidment, 2020). 
In addition, the modeling of the rain-flow transformation requires the use of two models: a production model for net rainfall and a transfer model characterizing, in particular, water losses by infiltration (Chane Poi Sane, Noel, Sampic, \& Xie, 2011) (transfer function and base discharge).

There are many models that can be divided into three main categories: empirical models, conceptual models and physics-based models (Refsgaard \& Storm, 1995). «Conceptual models are the most widely used since they have the advantage of representing the physical processes internal to watersheds at the event or continuously in a more realistic way than empirical models» (Regazzon, Payraudeau, \& Grégoire, 2010). In addition, the use of the model can be used to estimate flows from rainfall data and to assess the consequences of human interventions in the watershed such as land use changes and increasing urbanization.

The HEC-HMS model (Hydrologic Engineering Center - Hydrologic Modeling System) is a conceptual hydrological model (Skoulikaris, 2008), Therefore, our choice is based on the HEC HMS spatialized conceptual model for the following reasons:

- Coupling the model with geographic information systems allows a better understanding of the geographic complexity of the watershed;

- The reliability of the results obtained.

The following figure illustrates the steps involved in hydrological modeling of a watershed.

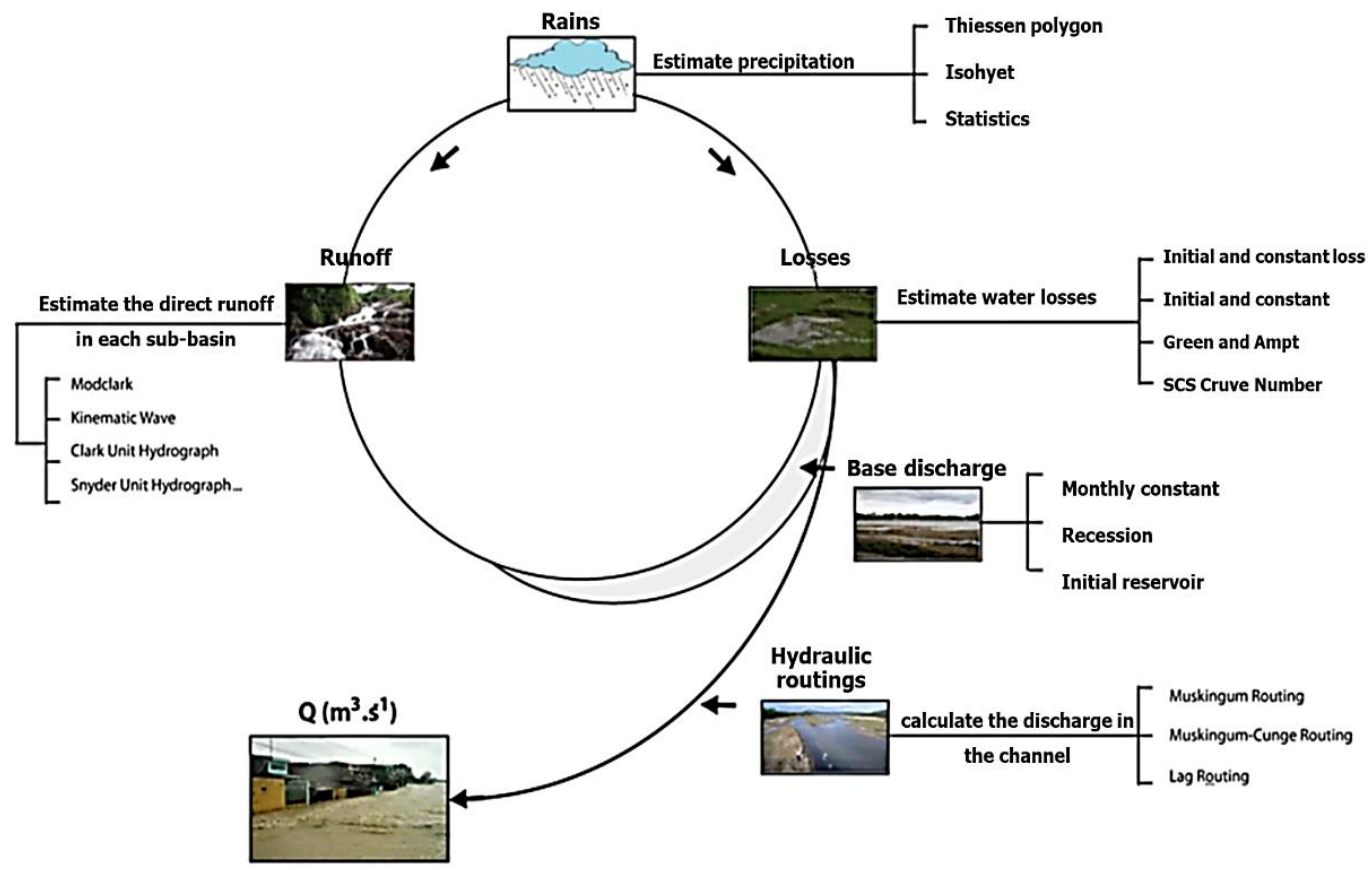

Figure 2. Conceptual diagram of the hydrological functioning according to the HEC-HMS model(

\section{Methodological approach to modeling}

Identification of flood hazard goes beyond identifying treats and the extent of damage caused by floods but also identifying the factors responsible for the increasing flood incidence, the vulnerability of the community and the strategies to mitigate the adverse effects of the flood (Ajodo \& Olawepo, 2021). It is essential to apply effective preventive measures to achieve an acceptable level of protection and reduction of damage to people and their property. The methodology consists of two steps. The first phase, the hydrological modeling of the watershed which aims to understand its functioning through the use of HEC-GeoHMS and the spatial analyst extension. The HECGEOHMS operates in a DEM via GIS to carry out the delimitation in sub-watersheds and the 
hydrographic network. Then it allows to estimate the hydrological input parameters in the model (HMS Inputs) such as the concentration time, the longest hydraulic path, etc. (US Army Corps of Engineers (USACE), 2000).

The second phase consists of determining the calculation methods for the production function, the transfer function and the type of base flow adopted. Starting from the DEM of $12.5 \mathrm{~m}$ resolution from Advanced Land Observation Satellite, the following operations allow the schematization of the watershed to be obtained.

\section{Schematization of the watershed model}

Filling of cuvettes

The purpose of this function is to fill the depressions in order to eliminate the deformations of the DEM. A depression is a cell whose drainage direction is undefined.

Flow direction

A flow direction grid consists of values that indicate the neighboring cell from which the water will flow. The cell values are the flow directions, which can only have eight possible directions for the water flow (eight-direction flow point).

This function determines the flow direction for the river system in the study area. The values in the cells of the flow direction grid show the direction in the direction of the fastest slope of each cell. Create a flow direction raster from each cell to its largest downslope neighbor (ESRI). There are eight valid exit directions relative to the eight adjacent cells in which the flow can flow. This method is generally referred to as the eight-direction flow model (D8).

\section{Flow Accumulation}

The flow accumulation is calculated from the direction of flow. From a physical point of view, the flow accumulation grid is the drainage area measured in units of grid cells. Therefore, it indicates how many cells are upstream or upstream of the current cell.

The use of the Flow Accumulation tool allowed us to create an accumulated flow raster for each cell, according to the accumulation of the weights of all these cells flowing into the downsloping cells.

\begin{tabular}{|l|l|l|l|l|l|}
\hline 78 & 72 & 69 & 71 & 58 & 49 \\
\hline 74 & 67 & 56 & 49 & 46 & 50 \\
\hline 69 & 53 & 44 & 37 & 38 & 48 \\
\hline 64 & 58 & 55 & 22 & 31 & 24 \\
\hline 68 & 61 & 47 & 21 & 16 & 19 \\
\hline 74 & 53 & 34 & 12 & 11 & 12 \\
\hline
\end{tabular}

Elevation surface
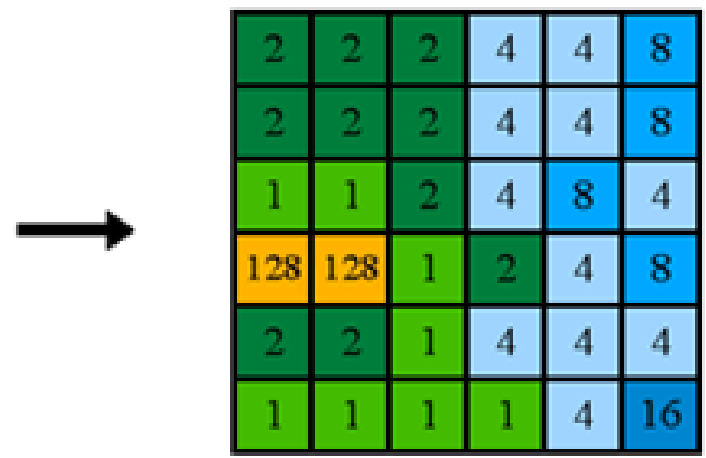

Flow direction

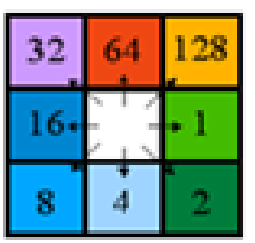

\section{Direction coding}

Figure 3. The principle of flow direction coding. (Source: ESRI) 


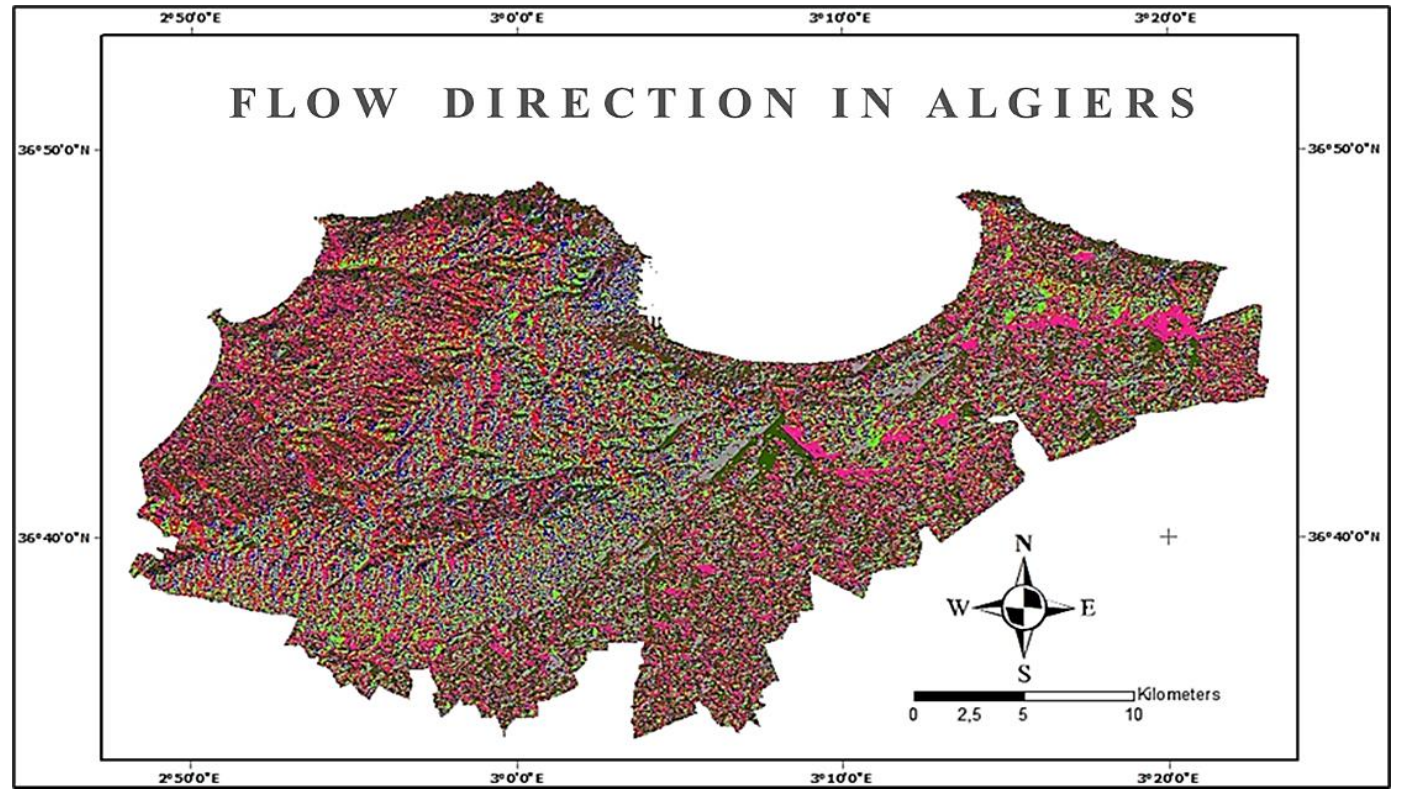

Figure 4. Map of flow direction

(Source: Khouas Makhlouf Adel)

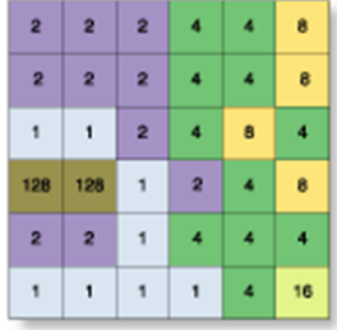

Flow_Dir

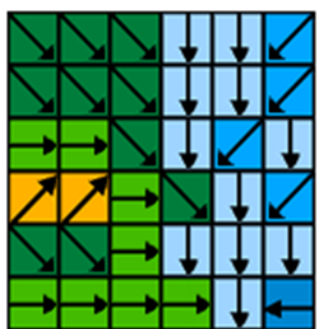

Flow direction

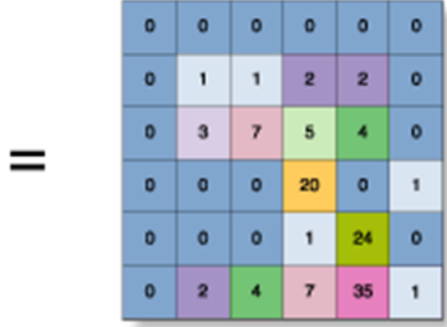

Flow_Acc

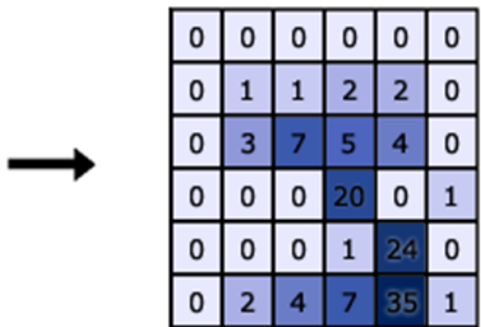

Flow accumulation

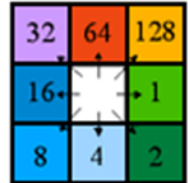

Direction coding

Figure 5. The principle of coding of Flow Accumulation (Source: ESRI) 


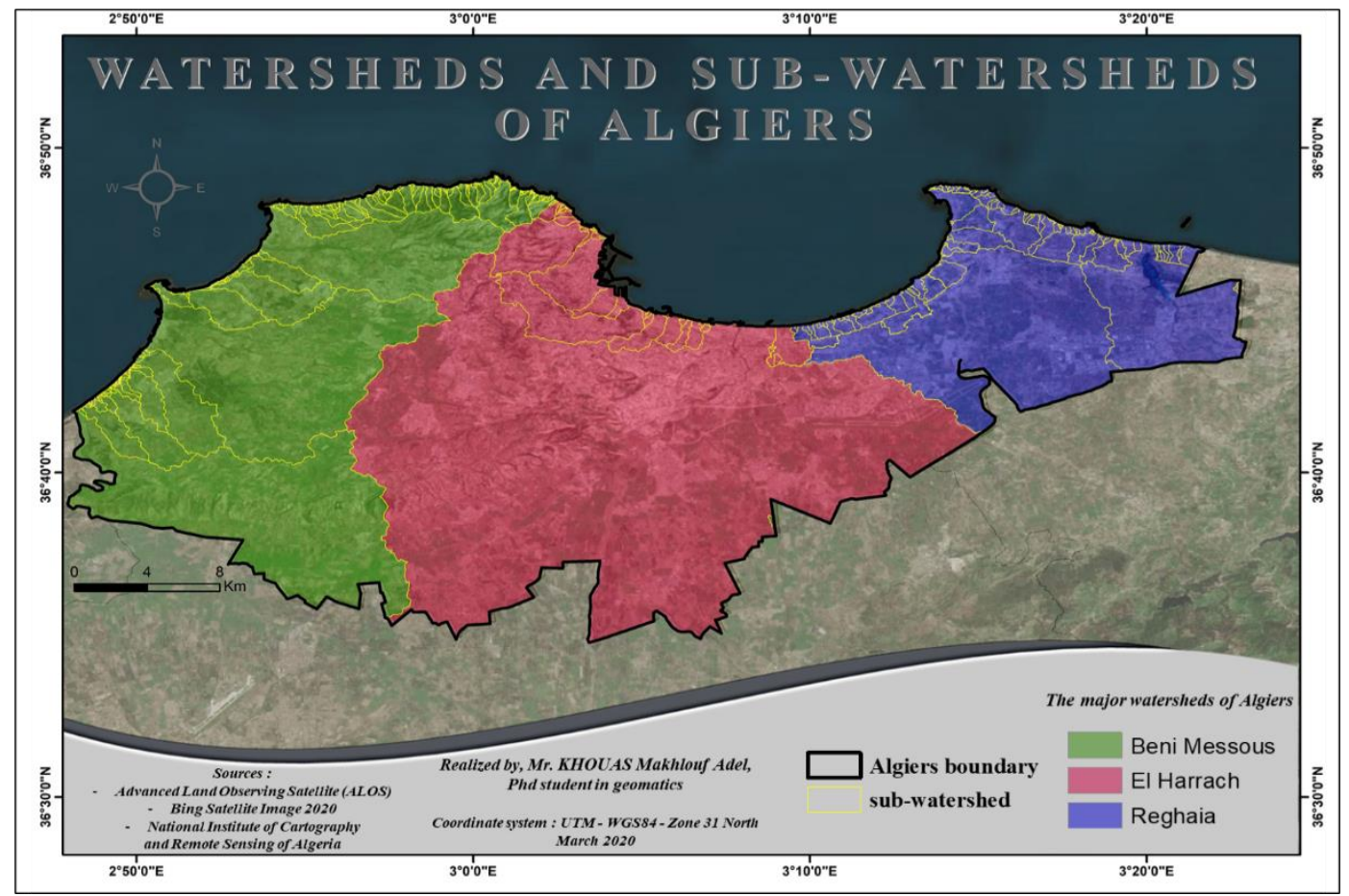

Figure 6. Map of delimitation of the impluvium of Algiers (Source: Khouas Makhlouf Adel)

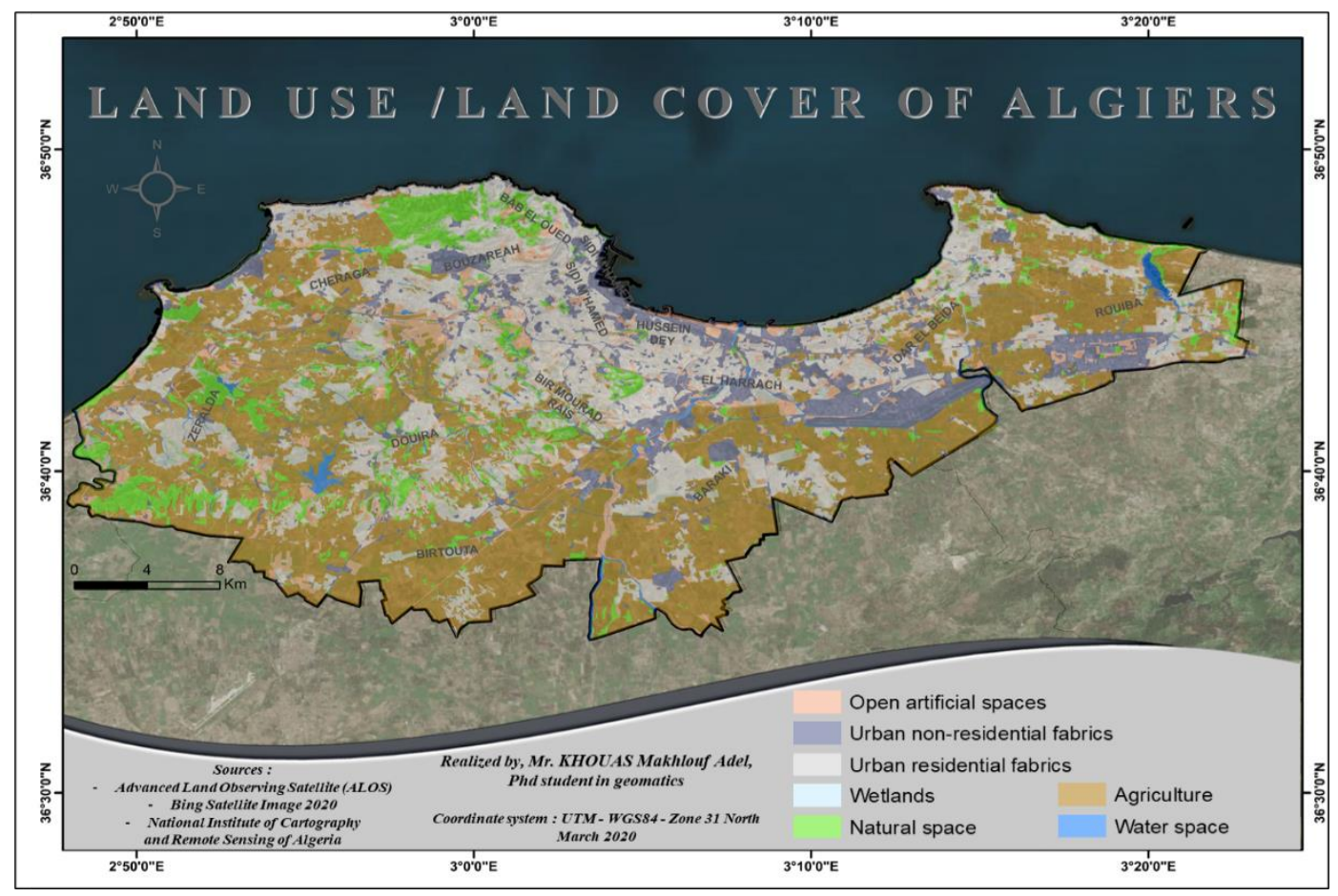

Figure 7. Map of Land use/Land Cover of Algiers (Source: Khouas Makhlouf Adel) 


\section{- Flow direction}

This function calculates a flow grid based on a flow accumulation grid. Cells in the input flow accumulation grid that have a value greater than a threshold (optional), assign a value of 1 in the flow grid. The purpose of this step is to extract the hydrographic network from the accumulation of flows, which represents a network of flows (Guellouh, 2017).

- Segmentation of the flow network

Segmentation of the flow network is the operation of assigning a unique code for each segment. Moreover, identical cells carry the same network code.

The nodes considered are the sources, junctions and outlets. Contiguous pixels between two nodes will have the same segment ID and each segment will be numbered differently (Atilio, 2015).

- Delimitation in sub-basins

This function consists of delineating the sub-basins for each stream segment. It allows to create a grid of cells that have a code for each sub-basin.

To do so, it is essential to first determine the outlet of the watershed, which requires a detailed knowledge of the study area, it is therefore necessary to create a class of entity point and locate the outlet. Then the watershed function is performed.

- Conversion of sub-basins to vector format

This step converts the raster representation of sub-basins to vector mode. The conversion is done by the Raster to Vector conversion tool of Arc Toolbox.

- Conversion of the hydrographic network to vector mode

This step converts the grid representation of the hydrographic network to the vector representation by the Raster to Vector conversion tool of Arc Toolbox.

- Land Use/ Land Cover

The determination of the land cover classes was carried out on a sentinel satellite image using GIS software, and the land use classes were determined following a field survey.

The themes we have chosen are: Agriculture, Water space, Wetland, Natural space, Open artificial spaces, Urban non-residential fabrics, Urban Residential Fabrics.

\section{Stream and Watershed Characteristics}

The morphological characteristics of a watershed are factors that play a major role in the genesis of floods. The province of Algiers is divided into three main drainage basins: the Beni Messous basin (West), the El Harrach basin (Center) and the Reghaïa basin (East). These watersheds are characterized, to the west, by a complex network associated with the mountainous coastal system of the Sahel which integrates a large number of streams, steeped along the valleys, and to the east, on the plain of Mitidja, by a network sitting on vast valleys and almost flat that emerge between the Bay of Algiers and the eastern coastal platform (Algiers urban planning department, 2016).

\section{Production function}

The production function is the equation that measures the difference between gross and net rain by subtracting infiltration.

To estimate water losses by infiltration, the HEC-HMS $\subset$ model has different methods: Green and Ampt, SCS (Soil Conservation Service), Curve Number, initial and con stant deficit, initial and constant losses, Smith Parlange (US Army Corps of Engineers (USACE), 2000). Among these methods, we have opted for the SCS (Soil Conservation Service) Curve Number method.

The key parameter of the SCS-CN model is the curve number which depends on land cover, hydrological soil group (HSG) and antecedent moisture conditions (AMC).

The production function that was used is the USDA Soil Conservation Service (SCS) function that links the cumulative effective rainfall $\mathrm{Pe}$ to the cumulative gross rainfall $\mathrm{Pb}$ (Steenhuis, Winchell, Rossing, \& Zollweg, 1995), by the equation: 
Where,

$$
P_{e}=\frac{\left(P-I_{a}\right)^{2}}{\left(P-I_{a}+S\right)}
$$

Pe: Excess precipitation;

P: The total precipitation accumulated at time $t$;

Ia: Initial losses;

$\mathrm{S}$ : The maximum retention potential.

$\mathrm{CN}$ can be estimated from two parameters; land cover and soil type.

\section{Runoff estimation}

\section{Transfer function}

The transfer function is the process of transforming rainfall into discharge at the outlet. The HEC-HMSC model proposes six different methods for estimating flows resulting from direct runoff in each sub-basin: Clark unit hydrographs, of SCS and Snyder, user-defined hydrographs, transformation and as well as Modclark kinematic waveforms (Tramblay, 2012). For this study, the SCS and Snyder method was used.

Hydrological parameters

The SCS Curve Number (CN) method is simple to implement (Soulis \& Valiantzas, 2012).

Table 1. SCS soil groups and infiltration rates

(Source: (Skaggs \& Khaleel, 1982))

\begin{tabular}{|c|l|c|}
\hline Group & \multicolumn{1}{|c|}{ Description } & Loss rate (in / hour) \\
\hline A & Deep sand, deep loess and silts & $0: 30-0: 45$ \\
\hline B & Shallow loess and silts & $0: 15-0: 30$ \\
\hline C & Silty clay, shallow sandy Silts, soils poor in organic matter & $0: 05-0: 15$ \\
\hline D & Clay, alkaline soil, heavy plastic clays & $0: 00-0: 05$ \\
\hline
\end{tabular}

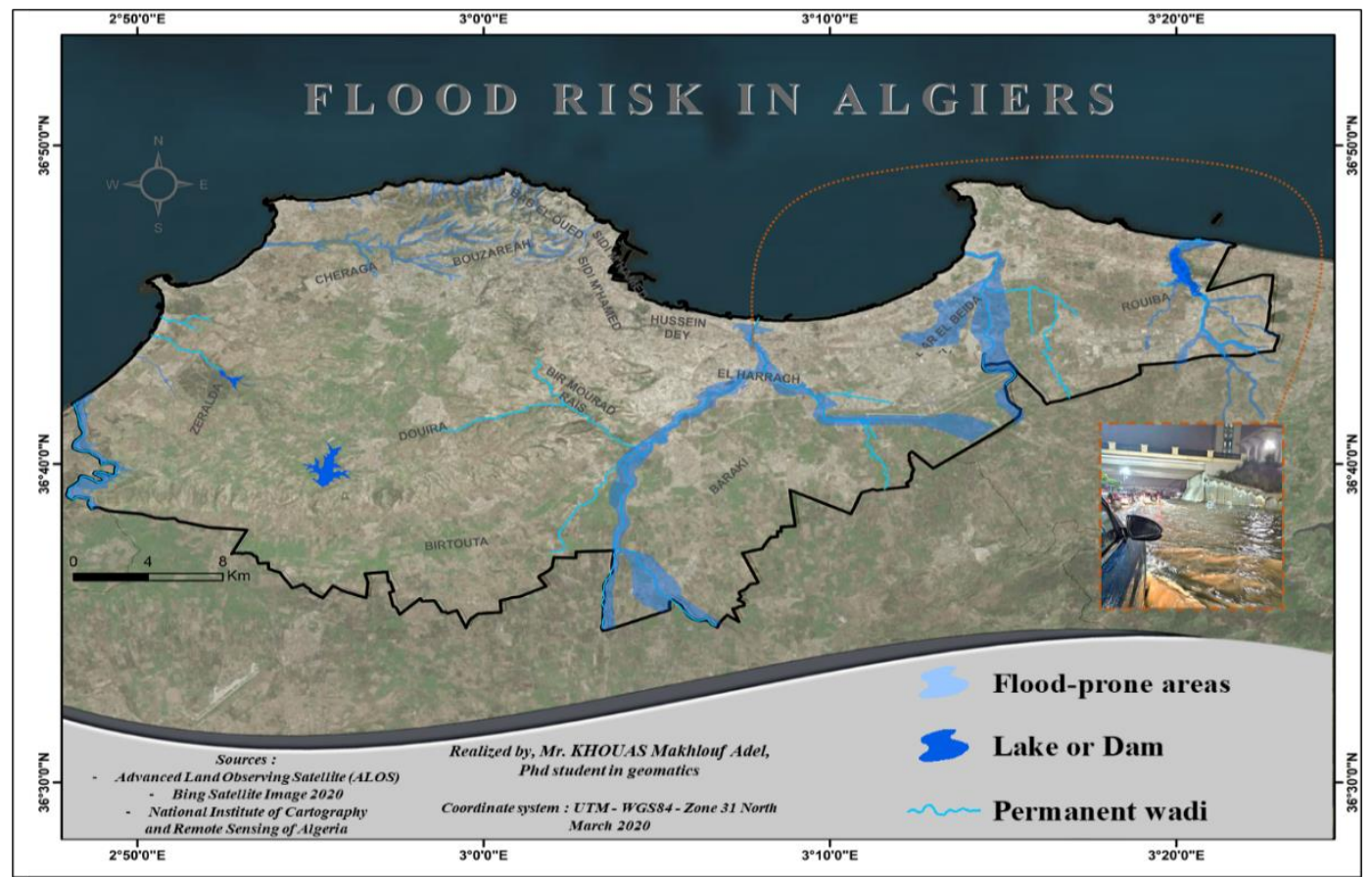

Figure 8. Flood Risk map (Source: Khouas Makhlouf Adel) 
The different characteristics of the sub-basins (length, slope, etc.) must be recorded in a file (basin) that will be used during the simulation made by the HEC HMS application.

\section{Results and discussion}

In the light of the various intervening parameters, we tried to reuse the HEC-HMS model adjusted to the impluvium of the city of Algiers to predict its response to a scenario taking the current reality of land use and a hundred-year return precipitation flow.

The result allows us the spatialization of the flood hazard and especially the result that interests us concerning the level of hazard in urban areas.

The extraction of the final result of the spatialization of the flood phenomenon allows us the integration of the result in the forecast on the possible scenarios of management and prevention in real time, the result is attached to the accuracy of the data and the resolution of the satellite images used.

\section{CONCLUSION}

The HEC HMS model is a tool for modeling the flood genesis process. It is part of a preventive approach to disaster management related to floods in urban areas. This HEC-HMS hydrological modeling system is a very flexible software used to model the rain-flow process in the watershed of the Algiers region. This hydrological modeling constitutes a schematization of the watershed in the simulation of a rainy phenomenon under the HEC-HMS software which must respect three main steps: watershed modeling, meteorology modeling and special specifications.

Based on the above, we are able to recognize the impact of a few situations that are likely to arise in the field in the coming decades, and that the persons in charge are supposed to take into consideration in their planning of the watershed of the city of Algiers. In addition, we were able to reconfirm that the cause-and-effect relationship between land cover change on the one hand and flows and volumes on the other, is less and less close as the showers are extreme.

Nevertheless, we believe that the use of official data from future projections will make it possible to simulate situations that are more realistic and more accurate than those proposed. Even better will be the benefits derived from this behavior prediction study, if we use the semi-distributed (sub-watershed) or squarely distributed (meshed) form of the HEC-HMS model.

\section{REFERENCES}

Ajodo, A. E., \& Olawepo, R. A. (2021). Flood Vulnerability and Incidence in Ibaji Local Government Area of Kogi State, Nigeria. Analele Universităţii din Oradea, Seria Geografie, 31(1), 57-67. doi:https://doi.org/10.30892/auog.311107-854

Algiers urban planning department. (2016). Plan directeur d'aménagement et d'urbanisme de la wilaya d'Alger.

Atilio, F. (2015). Blog GIS \& Territories. Le blog SIG pour al gestion territoriale.

Beckers, E., \& Degré, A. (2011). La prise en compte des transferts horizontaux dans les modèles hydrologiques. Biotechnology, Agronomy and Society and Environment, 15(1), 143-151.

Castro, C. V., \& Maidment, D. R. (2020). GIS preprocessing for rapid initialization of HEC-HMS hydrological basin models using web-based data services. Environmental Modelling \& Software, 130. doi:https://doi.org/10.1016/j.envsoft.2020.104732

Chane Poi Sane, P., Noel, P., Sampic, C., \& Xie, L. (2011). Modèle numérique de prévision des inondations. Application à la prévision de la crue centennale du Lez. Projets "Eau et Environnement".

Fouchier, C. (2010). Développement d'une méthodologie pour la connaissance régionale des crues. Thèse de doctorat de l'université Montpellier II.

Gnouma, R. (2006). Aide à la calibration d'un modèle hydrologique distribué au moyen d'une analyse des processus hydrologiques: application au bassin versant de l'Yzeron. Thèse de doctorat à INSA de Lyon.

Guellouh, S. (2017). L'impact du recouvrement des oueds de Batna sur la dynamique des écoulements et les risques associés. Thèse de doctorat. Institut des sciences de la terre et l'univers, Université de Batna 2. 
Refsgaard, J., \& Storm, B. (1995). Computer Models of Watershed Hydrology. In V. P. Singh, Water Resources Publications (pp. 809-846). Englewood.

Regazzon, C., Payraudeau, S., \& Grégoire, C. (2010). Synthèse bibliographique des outils d'évaluation du ruissellement. Project Enrhy.

Sami, G., Adbelwahhab, F., Yahyaoui, H., \& Abdelhhani, F. (2021). Flood Hazard in the City of Chemora (Algeria). Analele Universităţii din Oradea, Seria Geografie, 31(1), 22-27.

Skaggs, R., \& Khaleel, R. (1982). Hydrologic Modeling of Small Watersheds. In C. Haan, H. Johnson, \& D. Brakenstek, An ASAE Monograph Number 5 in a Series. American Society of Agricultural Engineers.

Skoulikaris, C. (2008). Modélisation appliquée à la gestion durable des projets de ressources en eau à l'échelle d'un bassin hydrographique: le cas du Mesta-Nestos. Thèse doctorat, Paris Tech.

Soulis, K., \& Valiantzas, J. (2012). SCS-CN parameter determination using rainfall-runoff data in heterogeneous watersheds - the two-CN system approach. Hydrology and Earth System Sciences, 16, $1001-1015$.

Tramblay, Y. (2012). Modélisation des crues dans le bassin du barrage Makhazine, Maroc. Institut de Recherche pour le Développement Hydrosciences-Montpellier.

US Army Corps of Engineers (USACE). (2000). Hydrologic Modeling System HEC-HMS Technical Reference Manual. Hydrologic Engineering Center.

Submitted: January 6,2021
Revised:

September 9, 2021
Accepted and published online December 2, 2021 